\title{
economics-of-security.eu
}

Faisal Rabby and William M. Rodgers III

\section{Post 9-11 U.S. Muslim Labor Market Outcomes}

October 2009

Economics of Security Working Paper 19

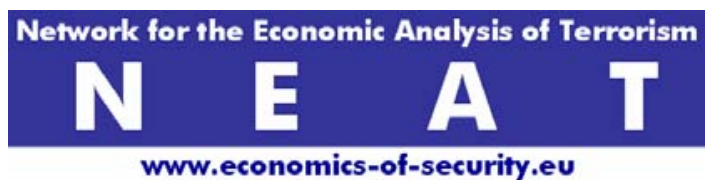


Economics of Security Working Paper Series

Correct citation: Rabby, F. and Rodgers, W. M. (2009). "Post 9-11 U.S. Muslim Labor Market Outcomes". Economics of Security Working Paper 19, Berlin: Economics of Security.

First published in 2009

(c) Faisal Rabby and William M. Rodgers III 2009

ISSN: 1868-0488

For further information, please contact:

Economics of Security, c/o Department of International Economics, German Institute for Economic Research (DIW Berlin), Mohrenstr. 58, 10117 Berlin, Germany.

Tel: $+49(0) 3089789-277$

Email: neat@diw.de

Website: www.economics-of-security.eu 


\title{
Post 9-11 U.S. Muslim Labor Market Outcomes
}

\author{
Faisal Rabby \\ Missouri State University \\ 901 S National Avenue, Strong 371 \\ Springfield, MO 65897 \\ Phone: 848-391-5001 \\ Fax: 417-836-4236 \\ faisalrabby@missouristate.edu \\ and \\ William M. Rodgers III \\ Rutgers, the State University of New Jersey \\ 30 Livingston Avenue, Room 203 \\ New Brunswick, NJ 08901 \\ Phone (732) 932-4100, x6203 \\ Fax (732) 932-2039 \\ E-mail: wrodgers@,rutgers.edu
}

JEL Classification: J15, J61, J71

An earlier version of this paper was presented at the meetings of the Southern Economic Association, November 2008. We thank Reed Olsen, Anne Piehl, John Landon-Lane and Ira Gang for helpful comments and suggestions. 


\begin{abstract}
Using a difference-in-differences framework and micro data from the Current Population Survey-Merged Outgoing Rotation Group Files (1999 to 2004), this paper estimates the impact that the 9-11 terrorists attacks had on the U.S. labor market outcomes of individuals with nativity profiles similar to the terrorists. We find that shortly after the attacks, the employmentpopulation ratios and hours worked of very young (ages 16 to 25) Muslim men fell. By 2004, most losses had begun to dissipate. The employment-population ratios and hours worked of older Muslim men experienced little deterioration.
\end{abstract}

JEL Classification: J15, J61, J71 


\section{Introduction}

The 9-11 terrorists attacks generated a significant amount of animosity towards Arabs and Muslims living in the United States. The Council on American-Islamic Relations (CAIR) reported a 64\% increase in discrimination complaints by the end of 2002. In 2003 and 2004, complaints increased by $70 \%$ and $49 \% .{ }^{1}$ Further, CAIR reported civil rights violations increased, with 18 to 26 percent of the reported violations occurring in the workplace. ${ }^{2}$

Survey data also indicates an increase in discrimination. A 2007 PEW research center survey of 1,050 Muslim adults living in the U. S. found that 53\% of all respondents agreed that since the 9-11 attacks it had become more difficult to be an American Muslim. Interestingly and very important for our analysis, younger Muslims (ages 18-29) more frequently reported being the object of suspicion ( $32 \%$ in contrast to $22 \%$ of older Muslims).

The U.S. government's policy and legal responses to the 9-11 attacks generated feelings of anxiety and isolation for Muslims. ${ }^{3}$ The executive branch implemented a number of antiterrorism programs. These programs translated into a difficult legal environment for certain Arabs and Muslims. Some of the initiatives were targeted towards categories of non-citizens. Mass round-ups of predominantly Arab and Muslim immigrants started weeks after 9-11. Other initiatives include the special registration program (initiated in November 2002 and abolished in December 2003); "voluntary" interviews (about 13,434 interviewees were placed in removal proceedings for visa violations); the Justice Department's efforts to involve local police in the enforcement of federal immigration law; and holding Muslim detainees without charge. Arab and Muslim organizations described these programs as detrimental to community relations.

Estimates of the impact that 9-11 had on Muslim labor market outcomes have emerged. Dávila and Mora (2005) find that between 2000 and 2002 (2001 excluded), Arabs and Muslims experienced a significant decline in earnings as compared to non-Latino Whites (those who speak only English at home). Their interpretation is that the 9-11 attacks affected the labor market outcomes of demographic groups that most closely match the terrorists' ethnicity. Their sample included men between the ages of 25 and 40 who worked at least twenty hours per week and for thirty-two weeks or more in the survey year. Their target group included men from Afghanistan, Pakistan, Iran, and the Middle-eastern Arab countries. ${ }^{5}$

Kaestner, Kaushal, and Reimers (2007) find that the 9-11 attacks were not associated 
with a reduction in the employment and hours worked of Arabs and Muslims. However, the attacks were associated with about a 14 to 16 percent decline in the real weekly earnings of 21 to 54 year old Muslim and Arab men. Kaestner et al. find that changes in occupation and industry account for some of the decrease in wages. They infer that the distribution of Arab and Muslim men by occupation and industry changed after 9-11 and that these changes adversely affected earnings of Arab and Muslim men. Kaestner et al. also find that internal migration of Arabs and Muslims decreased after 9-11. This is suggestive of a decline in the returns to mobility. Finally, they show that over time, the adverse impact of 9-11 dissipated.

Orrenius and Zavodny (2005) estimate 9-11's affect on the earnings of 18 to 39 year old male Latino immigrants who have, at most, completed a high school education. They estimate difference-in-differences models and find no effect on employment, but they do find a 4 to 7 percent decrease in hours worked and a 3 to 6 percentage point drop in the employment of Latino immigrants relative to Latino natives.

These three studies utilize a variety of outcomes, periods of observation, ages, labor force attachments, and different control groups. This paper attempts to unify these three studies and answer the following questions. Did the labor market outcomes worsen for Muslims (i.e. immigrants from Muslim-majority countries) after 9-11, particularly for Muslims whose demographic profiles closely fit those of the terrorists? Was the deterioration short-lived (i.e. did they dissipate overtime)?

Using the Census Bureau's Current Population Survey (CPS) micro data from 1999 to 2004 and a difference-in-differences (DD) methodology, we estimate impacts for all men between 16 to 64 years of age and age sub-groups (e.g., 16 to 25). We estimate DD models for three outcomes: employment-population ratio, hours worked, and earnings. We estimate impacts using three target groups and three control groups. Finally, we perform several robustness checks. In particular, we incorrectly specify the dates of the attacks in the difference-indifferences models.

We find that 9-11 and the anti-terrorism measures were associated with a relative decrease in employment, hours worked, and the earnings of immigrants from Muslim-majority countries. The largest decreases were among the youngest immigrant men (ages 16 to 25) from the Middle East (excluding Israel), Iran and Afghanistan, whose demographic profiles are the closest to the terrorists. Most significant is the finding that even for the youngest men, the 
adverse impacts appear to be short lived. Many of the estimated losses dissipate by the end of 2004.

\section{Methods}

Our central method is difference-in-differences, where we compare the change in the employment-population ratio, usual hours worked per week, and real weekly earnings of a target group to that of a comparison group. ${ }^{6}$ Thus, we attempt to remove the impact that labor supply, labor demand and institutional factors have on target-group outcomes. ${ }^{7}$

More formally, outcomes are described as follows:

$$
\begin{aligned}
& \mathrm{Y}_{\text {ist }}=\beta_{0}+\beta_{1} \text { After }_{\mathrm{t}}+\beta_{2} \text { Muslim }_{\text {ist }}+\beta_{3}\left(\text { After }_{\mathrm{t}} * \text { Muslim }_{\text {ist }}\right)+\beta_{4} \mathrm{X}_{\text {ist }}+\beta_{5}\left(\mathrm{X}_{\text {ist }} * \text { Muslim }_{\text {ist }}\right) \\
& +\beta_{6} \mathrm{Z}_{\mathrm{st}}+\beta_{7}\left(\mathrm{Z}_{\mathrm{st}} * \text { Muslim }_{\text {ist }}\right)+\beta_{8} \text { Quarter }+\beta_{9}\left(\text { Quarter }_{\mathrm{t}} * \text { Muslim }_{\text {ist }}\right)+\beta_{10} \text { State }_{\mathrm{s}} \\
& \left.+\beta_{11} \text { (State }_{\mathrm{s}} * \text { Muslim }_{\text {ist }}\right)+\beta_{12} \text { Trend }_{\mathrm{t}}+\beta_{13} \text { Trend }_{\mathrm{t}} * \text { Muslim }_{\text {ist }}+\mathrm{u}_{\text {ist }}
\end{aligned}
$$

where $Y_{\text {ist }}$ is the labor market outcome of person $i$ in state $s$ at time $t$. The term After is a dummy variable that equals one if the observation comes from any month after September 2001, and zero otherwise. The term $X_{\text {ist }}$ denotes a vector of individual characteristics that include potential experience, education, race and ethnicity, marital status, length of stay in the US, citizenship status, and generation in the US. In our earnings equations, $X_{\text {ist }}$ contains occupation and industry indicators. $^{8}$

The term $Z_{\text {st }}$ represents the state unemployment rate, Quarter $_{t}$ is the interview quarter (ranging from 1 to 4 ) to capture seasonality and Trend ${ }_{t}$ is as a cubic function of time (starting from 1 for January 1999), capturing unmeasured, time-varying influences. ${ }^{9}$ The notation State $\mathrm{s}$ represents dummy variables that capture differential effects of location. The coefficient $\beta_{3}$ on the interaction of After ${ }_{t}$ and Muslim ${ }_{\text {ist }}$ identifies the difference-in-differences effect of 9-11 on the labor market outcomes of Muslims. ${ }^{10}$

Most of the effects are allowed to differ by the Muslim status. This is done to allow for the fact that some factors like the business cycle, and citizenship status, might have affected the two groups differently over time. Two recent reports by the American-Arab Anti-Discrimination 
Committee (Ibish and Stewart 2003) and the Council on American-Islamic Relations (CAIR 2002 to 2005) suggest that discrimination varied by location. However, other than using the state/region dummies and Muslim to "non-Muslim" population ratios as an index of their visibility, no control is used for this variation across locations. ${ }^{11}$

The key to identifying the impact of the terrorists' attacks on Muslim labor-market outcomes is the proper construction of target and comparison groups. Previous studies use a limited set of target and comparison groups. We demonstrate that there are additional considerations when constructing these groups. First, the impact of 9-11 on the labor-market outcomes of Muslims and Arabs varies by age. New job-market entrants might have experienced different outcomes than experienced workers. Given the terrorists' profiles, younger Muslims/Arabs may be more vulnerable to discrimination. ${ }^{12}$ Second, the labor market outcomes of Muslims might have been affected by the laws and programs created after 9-11 as well as by the animosity and fear that emerged after 9-11. To operationalize these ideas, we create several target groups consisting of either Muslim men or immigrant men from Muslim-majority countries.

\section{Data and Results}

We use the 1999 to 2004 Current Population Survey (CPS) Merged Outgoing Rotation Groups files. The micro data sample is restricted to men who at the time of the survey were 16 to 64 years old and were not enrolled in school. The construction of the target and comparison groups and some salient features of the samples are described below.

\section{A. Target and Comparison Groups}

Religious affiliation is the appropriate information for categorizing whether an individual is Muslim, but the CPS does not contain this information. However, the CPS contains the reference person's country of birth as well as their parents' nativities, which makes it possible to identify $1^{\text {st }}$ and $2^{\text {nd }}$ generation immigrants from most Muslim-majority countries. We use this nativity information to define whether an individual is Muslim. We think this is a good proxy for determining whether an individual is Muslim. Evidence suggests that people did not discriminate against Muslims with much accuracy after 9-11. ${ }^{13}$ News reports and other studies find cases where non-Muslims with Muslim appearances experienced work place backlashes. ${ }^{14}$ In many 
instances, it is very difficult to distinguish Arab Christians from Arab Muslims by name and appearance.

Further, country of birth also links up with the US government's special registration program. Most of the Muslim-majority countries (except Turkey and Malaysia) were on the Department of Justice's "Special Registration" list. ${ }^{15}$ In November 2002, the first in a series of call-in requirements was imposed on men from these countries. It required men from these countries to report and register with the Immigration and Naturalization Service. The CPS contains geographic information that allows us to identify 12 of the program's 24 countries. Nine countries are combined in two regions: the "Rest of North Africa" and the "Rest of Middle East" which excludes Israel. Two countries, Somalia and Eritrea are mixed with the CPS's "other African countries" category. Countries in this category were not included in the special registration program. Thus, we can not identify Muslims from Somalia and Eritrea. ${ }^{16}$

We construct three target groups (i.e., three groups of Muslims). Target Group C, the broadest group consists of $1^{\text {st }}$ and $2^{\text {nd }}$ generation immigrants from all of the special registration countries identifiable in the CPS: Afghanistan, Bangladesh, Egypt, Indonesia, Middle Eastern Arab countries (Bahrain, Jordan, Kuwait, Iraq, Lebanon, Oman, Qatar, Saudi Arabia, Syria, United Arab Emirates, and Yemen), Iran, Libya, Morocco, North Africa and Pakistan. ${ }^{17}$ Turkey, Indonesia and Malaysia are Muslim-majority countries but were not listed under the special registration program. There has been relatively little evidence that the immigrants from these countries experienced intolerance after 9-11. India has the $2^{\text {nd }}$ largest Muslim population but it is not clear whether non-Muslim and non-Sikh Indians experienced discrimination. ${ }^{18}$ So neither target nor comparison groups include immigrants from these countries.

Immigrants from Bangladesh, Indonesia, and North Africa (except for Egypt and Morocco) do not fit as well as Arabs with the nativity and ethnic profiles of the 9-11 terrorists. Therefore, we create Target Group B, a sub-group that is closer to the terrorists in nativity and ethnicity. This group consists of $1^{\text {st }}$ and $2^{\text {nd }}$ generation immigrants from Afghanistan, Middle Eastern Arab countries, Iran, Pakistan, Egypt and Morocco - immigrants from these countries should be closer to the nativity and ethnic profiles of the terrorists.

The Iraq and Afghanistan wars, longstanding unrest in Palestine, and the Madrid Train Bombings might have made Arabs and Muslims from these regions targets for discrimination. To assess this possibility, we construct the narrowest sub-group, Target Group A, which consists of 
only men from Middle Eastern Arab countries, Iran, and Afghanistan, the terrorists' countries of origin. Finally, we limit the target samples to the 18 states in which 75 percent of Muslims live. ${ }^{19}$ We make this exclusion to keep the target groups' geographic concentration similar.

As the validity of the difference-in-differences approach largely depends on the comparison group's quality, we constructed three comparison groups. In developing the comparison groups, we attempt to select individuals who should not be impacted by post 9-11 intolerance but at the same time are similar to Muslims in terms of their observable characteristics. Ideally, unobserved factors contemporaneous to 9-11 should have the same effect on target and comparison group labor market outcomes.

Comparison Group 1 consists of $1^{\text {st }}$ and $2^{\text {nd }}$ generation immigrants from non-Muslimmajority countries. To keep the target and comparison groups similar in characteristics, we exclude $1^{\text {st }}$ and $2^{\text {nd }}$ generation Mexican, Central American, and Caribbean immigrants. ${ }^{20}$ Their observable characteristics such as education and U.S. legal status and possibly some unobserved characteristics are not very similar to immigrants in our target groups. To avoid additional contamination of the target and comparison groups, we excluded immigrants from Turkey, Malaysia, India, Ghana, Kenya, Nigeria and the CPS's "Other Africa” category, which contains Somalia and Eritrea. ${ }^{21}$

Comparison Group 2 consists of all US-born men excluding $2^{\text {nd }}$ generation immigrants from Target Group C: Mexico, Central America, the Caribbean, Turkey, Malaysia, India, Ghana, Kenya, Nigeria and Other Africa. As mentioned earlier, respondents from these countries are excluded from both the target and comparison groups to avoid possible contamination. Comparison Group 3 consists of all U.S. born non-Latino whites that are not in Target Group C. We exclude African Americans and Latinos from this group because some of their observable characteristics (e.g. education) are different from those of whites. Appendix I provides a summary description of the target and comparison groups.

\section{B. Descriptive Statistics}

Appendix II reports descriptive statistics for the youngest (ages 16 to 25) Muslim men and non-Muslim immigrant men (Comparison Group 1). ${ }^{22}$ The demographic characteristics of Comparison Groups 2 (all US born men) and 3 (US-born Non-Hispanic White men) are similar

to those for group 1 and are not reported here. ${ }^{23}$ There are two noticeable differences between the 
target and comparison groups, often irrespective of age. First, the target groups tend to have higher education (Bachelors degree and above) in contrast to all of the comparison groups. Second, the target groups are more concentrated in "Sales" occupations than the comparison group (21.2 to $25.0 \%$ versus $10.9 \%$ ). Third, target group individuals are more concentrated in "Distribution, Hotels \& Restaurants" industries than individuals in the comparison group.

Table 1 uses the cell means in Appendix II to construct non-regression adjusted difference-in-differences estimators. The Table shows that relative to Comparison Group 1, the employment-population ratio of very young Middle Eastern, Iranian and Afghan men (Target Group A) fell by 16.6 percentage points by the end of December 2002. The loss in employment is largely due to an 18-point drop in the employment-population ratio of the target group. By the end of 2004, 9-11's impact seems to have dissipated to only 2.5-percentage point drop, but this estimate has little statistical precision. We obtain a statistically significant yet smaller estimate for Target Group B (-0.119). For young men from all special registration countries (Target Group C), we obtain an even smaller estimated drop in employment, with little precision. Although the estimated gap by the end of 2004 indicates that the target group has a statistically significant advantage, it is only 1.0 percentage point.

The Table shows similar results for hours worked and real weekly earnings: target group outcomes typically decline shortly after 9-11 and recover by 2004. We attribute the decline in statistical significance to the greater variation in earnings and hours that must be explained compared to the simple binary employment variable.

In general, it is not clear from these basic estimates whether these adverse effects were caused by animosity towards Muslims, the laws/programs that followed 9-11, differences in labor supply, labor demand, and institutional characteristics of target and control groups. Our regression-adjusted difference-in-differences estimates attempt to account for these factors.

\section{Regression Results}

Table 2 reports the regression-adjusted difference-in-differences estimates $\left(\beta_{3}\right)$ of target groups A, B, and C relative to Comparison Group 1. The upper panel shows the effects for 1999 to 2002 and the lower panel reports the effects for 1999 to 2004, which enables us to demonstrate 9-11's immediate and short-term impacts. Each target group contains results for three age groups: 16 to 25,16 to 29 and 16 to 64 . Probit models were used to estimate the employment 
equations. The partial derivatives are reported. Their standard errors were estimated using the Delta method. Ordinary least squares is used to estimate the log weekly earnings and hours worked equations. For these log weekly earnings and hours worked equations, robust standard errors, clustered by repeated observations are shown in parentheses. ${ }^{24}$

In Table 2, the first row of the upper panel shows that shortly after 9-11, the employment gap among younger men between target and comparison groups widened. This gap narrows as one moves from only Middle Eastern, Iranian and Afghan men (Group A) to immigrants from all Special Registration countries (Group C). The employment gap among 16 to 25 year old men expanded by nearly 45.0 percentage points for Target Group A by 2002, much larger than the unadjusted estimate of 16.6 percentage points (Table 1). This short-term effect is 38 percentage points when Pakistani and African Arabs (Target Group B) are included and 29 percentage points when men from all other Special Registration countries (Target Group C) are added. All are measured with moderate precision.

Although large, the timing of these estimates corresponds to the year in which the reported number of civil-rights violations against Arabs and Muslims increased dramatically. The fact that 16 to 25 year old men comprise a very small fraction of the entire sample potentially makes the value of our findings dubious. However, when the sample's upper age limit is extended to 29 , we still obtain a 17.6 percentage point decline in relative employment for the broad target group (the effects for the narrow target groups were large and negative but not measured with precision). When we expand the sample to men aged 16 to 64 , we find no change in the employment of these target groups associated with 9-11.

Table 2's lower panel shows that by 2004 only very young men, particularly those from the Middle East, Iran and Afghanistan were still experiencing a relative decline in employment that is attributable to 9-11. The panel also reveals that there is no statistically significant effect of 9-11 on the employment of 16 to 29 and 16 to 64 year old men by 2004 . The simple inclusion of 25 to 29 year old men leads to a large dampening in 9-11's impact.

Switching to hours worked, we find that immediately after 9-11, there was a relative decrease in hours worked for the youngest target group. This is consistent with the relative decrease in their employment-population ratio as we set hours worked to zero for men who are not employed. By 2002, the narrow target group's hours worked diminished by 17 per week relative to Comparison Group 1. For the broad group, the relative decrease was about 11 hours. 
The decline in hours for the youngest Muslims persists through the end of 2004. The relative decrease was bigger for narrower groups (about 16 hours) than for the broad group (about 8 hours). It is possible that the elasticity of demand for young Muslims' labor increased after 9-11 due to rising animosity, fear, or legal stringencies. We find few statistically significant changes in hours worked for older Muslim men. Similar to the employment-population ratio estimates, the terrorist attacks appear to have had little impact on the hours worked of older Muslim men.

Weekly earnings have no distinct patterns that can be easily summarized. Shortly after 9-11, the earnings of Muslims in the narrow group (Target Group A) fall, with the largest erosion among 16 to 64 year old men. By 2004, the earnings disadvantage had largely dissipated. As we move to the Between Group, the pattern of losses among 16 to 64 year old men Muslims continues, but now young Muslims have an imprecisely measured advantage in 2002, which expands in 2004. This finding is even stronger in Target Group C.

What explains the earnings results? The decrease in earnings among 16 to 64 year old

Muslim men might have been caused by a rise in prejudice against or fear of Muslim men overall or by the increased anti-terrorism measures. Muslim men might have been forced to accept lower income from the same occupation or to switch from higher-income jobs to lower-income ones. Kaestner et al. (2007) find evidence that Arab and Muslim men were more likely to report switching from higher to lower-income occupations in the post-9-11 months. The puzzle lies with our estimates for 16 to 25 and 16 to 29 year old Muslim men. Our earnings models exclude the unemployed and those out of the labor force. Thus, we suspect that our DD estimates are biased due to nonrandom selection of lower-paid Muslims in to unemployment and departures from the labor force. Their exclusion raises the group's post-9-11 average earnings. The next section utilizes quantile regressions to explore this possibility.

\section{Robustness of Results}

Our findings that the employment of very young Muslim men deteriorated after 9-11 can be questioned on several grounds. First, during the post-9-11 years, the relative decline in the employment-population ratios and hours worked of young Muslims was accompanied by a relative increase in their average earnings (conditional on employment) for Target Group A in 2004, and Target Groups B and C in both 2002 and 2004. Second, for the narrow group of young Muslims, the number of observations is small. Third, the validity of our comparison groups can 
always be questioned. Fourth, the post-9-11 drop in the employment-population ratio of young Muslims might have been driven by a significant net emigration of non-citizen working Muslims who had to leave the US due to the anti-terrorism programs (e.g., deportation of certain types of non-citizens).

We address the first critique by estimating DD quantile regressions to show what appears to be a relative increase in the earnings of young Muslims can be attributed to employment loss by men concentrated in the lower tail of the earnings distribution. To address the additional critiques, we use pseudo-intervention dates in the difference-in-differences models. We explore the possibility whether increased net emigration was driving the results, and whether our results are sensitive to the use of additional comparison groups.

\section{Findings from Quantile Regressions}

It is important to note that the earnings equations in Table 2 were estimated only for employed men. If job loss for younger Muslims after 9-11 was concentrated in the lower tail of their earnings distribution, average earnings conditional on working are biased upward. If this form of selection is large enough, it could generate an increase in the target group's average wage that exceeds changes in the control group's average wage, thus explaining our estimates in Table 2. To assess the possibility of this type of bias, we estimate our difference-in-differences models using quantile regressions at the $25^{\text {th }}$, median, $75^{\text {th }}$ and $90^{\text {th }}$ percentiles of the earnings distribution. An individual's earnings are set equal to zero if they are not employed. Relative to the control group, if a larger portion of low-wage young Muslims left employment after 9-11, we should observe our anticipated Muslim disadvantage at the distribution's lower quantiles.

Table 3 reports the quantile regression estimates for all special registration countries (Target Group C), compared to other immigrants. The difference-in-differences effects are specific to the $25^{\text {th }}, 50^{\text {th }}, 75^{\text {th }}$ and $90^{\text {th }}$ percentiles. These patterns support our basic hypothesis that a form of selection occurred among young Muslims, but not the full sample of 16 to 64 year old Muslim men. The estimated median coefficient of -0.003 in the upper panel shows that for the youngest Muslims, median earnings did not change relative to non-Muslims. However, a 50 percent relative decrease is found at the $25^{\text {th }}$ percentile. By 2004, the disadvantage vanishes and becomes imprecisely measured at the $25^{\text {th }}$ percentile for 16 to 25 and 16 to 29 year olds. The middle panel reports that Muslims aged 16 to 29 had their median earnings rise by almost 14 
percent by 2002, compared to an imprecisely measured decline of 29 percent at the $25^{\text {th }}$ percentile. For 16 to 64 year old Muslim men, except for the $90^{\text {th }}$ percentile, their earnings decline at all quantiles.

We obtain our hypothesized results for Middle Eastern, Iranian and Afghans (Target Group A). The relative earnings of younger as well as older Muslim men fell at lower quantiles by $2004 .{ }^{25}$ This drop in earnings at the lower quantiles was accompanied with unchanged median earnings, which indicates that less-skilled and therefore low-earning young Muslims bore the brunt of the job losses, pushing their post 9-11 average earnings conditional on employment upward.

\section{Findings from using Different Intervention Dates}

As an identification check, we incorrectly specify the timing of the attacks. To do this, we estimate our difference-in-differences models for two sub-periods. The first uses data from January 1998 to August 2001 and the second uses data from September 2002 to December 2004). ${ }^{26}$ For the pre-9-11 sub-period, we set the Post 9-11 dummy variable equal to 1 if the observation corresponds to a date after August 2000. For the post-9-11 sub-period, the dummy variable equals 1 if the data corresponds to a month after September 2003.

For the full set of observations that run from January 1998 to December 2004, we also use a "rolling" date strategy. Here we set the attack date at a particular quarter and estimate the difference-in-differences model. We move the date forward by one quarter and re-estimate the model. The models are estimated for Target Groups A, B and C and comparison group 1.

Table 4 shows that for the January 1998 through August 2001 sub-period, with August 2000 as the intervention date, the difference-in-differences effects on the employment-population ratio, log hourly earnings, and weekly hours worked are often close to zero and are never statistically significant, even for the youngest men. Estimates for the post 9-11 sub-period, September 2002 through December 2004 with September 2003 as an intervention date, which are not shown here, reveal that there was an increase in the relative employment and hours worked of younger men from the Middle East, Iran and Afghanistan. However, this is consistent with our earlier finding that the impact of 9-11 on these young men began to dissipate between 2003 and 2004. In other words, this second set of months is not independent of 9-11's effects. ${ }^{27}$

Our "rolling" date strategy estimates thirteen (only the quarters from March 2001 to 
March 2003 are shown in Table 5 and Appendices III and IV) difference-in-differences models where each model corresponds to an intervention date between June 2000 and June 2003 . All of the estimates are regression adjusted and use data from 1999 through 2004. Choosing this wide range of dates pinpoints the narrow window when the outcome's (e.g., employment-population ratio) relative change occurred. The difference-in-differences estimates shown in Table 5 suggest that the relative decline in the employment-population ratio of the youngest Muslims occurred between September 2001 and December 2001. For each target group, the relative decrease in employment is the largest in the year after 9-11 and dissipates as the intervention date moves farther from September 2001. ${ }^{28}$

Consistent with the relative drop in employment, Table 5 also shows that hours worked decreased by 8 to 16 percent for the youngest group and the effects worsen as one moves from the broad to the narrow group. We find a similar pattern for the 16-to-29 year olds (Appendix III). However, only a 10 percentage-point decrease in the broad target group's employmentpopulation ratio is found when the longer time-window is considered. For 16 to 64 year old men (Appendix IV), we do not find a significant drop in employment at any "pseudo" intervention date. The above results confirm our earlier conclusions that employment deteriorated for the youngest members of the target group and the effects were short-lived, and older Muslim men were not heavily impacted by $9-11$.

The earnings regressions using the rolling intervention dates yield results consistent with the 1999 to 2004 estimates in Table 2. ${ }^{29}$ From June, 2001 to March, 2003, the differencein-differences estimates are positive. Young Muslims in each target group experience a relative increase in their earnings. The estimates reflect the impact of Muslim job losses that are concentrated at the lower tail of the earnings distribution. They persist well after the actual date of the attacks.

\section{Did Muslim Net Emigration from the US Explain their Labor Market Outcomes Deterioration?}

After 9-11, there is some evidence of increased net emigration of both target and comparison group individuals. We estimated the population of the two immigrant groups from the CPS-MORG files. We find that the number of immigrants from both the Special Registration countries and other countries was stable over this period. In fact, both groups experienced slight population declines from 2003 and 2004. For the Special Registration countries, the drop was 
approximately 65,000 and for the comparison-group countries the estimated decline was near 986,000. Even though the emigration numbers are different between the two groups, these decreases are not significant and occurred only in 2004. Furthermore, the decline in population for the two groups is proportional. Therefore, net emigration may not be a force driving Muslim labor market outcomes unless two things occurred: mainly non-citizens emigrated and a significant number of the outgoing non-citizen Muslims was employed in the US.

After 2001, the ratio of noncitizens-to-citizens decreased steadily until 2003 for the target group. The drop in the proportion of non-citizens is consistent with deportations and a significant fall in non-immigrant US-visa issuance after 2001, particularly for Special Registration countries. This change in the citizenship composition of the target group could have contributed to the relative decline. To check whether non-citizen emigration had any effect, we re-estimated the difference-in-differences models but restrict the Target Group $\mathrm{C}$ and Comparison Group 1 samples to US-citizens. We find that the estimates increase only slightly. If net emigration occurred mostly for employed non-citizen Muslims, our estimates are biased upward. However, the opposite scenario (e.g., increased net emigration of non-employed Muslims after 9/11) seems more plausible in which case our estimates are biased downward.

\section{Using US-Native Men as Comparison Groups}

As mentioned earlier, native-born men are not as good a comparison group as "nonMuslim" immigrants because the target groups differ from natives in terms of language proficiency. To assess whether this is true, we construct two additional comparison groups: Group 2 (US-born men other than members in target groups) and Group 3 (US-born non-Latino White Men other than members in target groups). The same regression models are estimated with these comparison groups. ${ }^{30}$ The estimates using the US-born men as comparison groups are similar to those using immigrants from non-Muslim countries. However, they are often not statistically significant. These estimates indicate that by 2002, employment dropped by about 20 percentage points (marginally significant at $10 \%$ level) for the youngest (age 16-25) immigrants from all special registration countries (Target Group C). For Arab, Iranian, Afghan and Pakistani men, this decrease is about 23 percentage points (significant at $10 \%$ level). For very young Middle Eastern Arabs, Iranians and Afghans, a 24 percentage-point relative drop in employment was not statistically significant but a 13-hour relative decrease in their work by 2004 is 
statistically significant at $1 \%$ level. For 16 to 64 year old men, there were approximately 16,15 and 10 percentage-point drops in earnings for Target groups A, B and C respectively relative to the US-born men. Use of Comparison Group 3, US-born non-Latino Whites yields qualitatively similar results (Available upon request).

\section{Summary and Conclusions}

This paper provides a comprehensive set of estimates of 9-11 and the associated antiterrorism measures' impacts on the labor market outcomes of Muslim men. Using a natural experiment framework, we find that labor market outcomes worsened for men with nativity profiles closer to the terrorists. Employment losses are greatest and longest in duration for very young (ages 16 to 25) Muslim men. Many of the estimated losses dissipate by the end of 2004, with weekly hours as the exception. Our results are similar to previous studies that include older individuals in their samples. When we include older individuals, the estimated losses are small and short-lived.

Our findings are consistent with the hypothesis of an emergence in discrimination against minorities that more or less fit the Muslim stereotype after the 9-11 terrorist attacks. However, the labor market's legal environment became relatively rigid for first-generation immigrants at least for a short period after 9-11. Because of these simultaneous changes, it is difficult to disentangle how much of the effects on labor market outcomes were caused by discrimination and how much by anti-terrorism legislation.

Two pieces of evidence are suggestive of a growth in discrimination against immigrant men. First, Muslims with age and nativity profiles closer to the terrorists' experienced larger declines in their employment. Second, the decline in employment and earnings of Muslims associated with 9-11 began to dissipate after 2002, just when some of the salient anti-terrorism programs and laws were initiated. Furthermore, the fear of discrimination might also have discouraged some minority workers from labor market participation. 


\section{References}

Baker, Wayne; Howell Sally; Jamal, Amaney; Lin, Ann; Shryock, Andrew; Stockton, Ron and Tessler, Mark. 2003. "The Detroit Arab American Study.” University of Michigan. Available at: http://www.umich.edu/news/index.html?Releases/2004/Jul04/r072904

Braakmann, Nils; Islamistic Terror, the War on Iraq and the Job Prospects of Arab Men in Britain: Does a Country's Direct Involvement matter? University of Lüneburg Working Paper Series in Economics No. 70, December 2007, www.leuphana.de/vwl/papers

Braakmann, Nils; The impact of September 11th, 2001 on the job prospects of foreigners With Arab background - Evidence from German labor market data; University of Lüneburg Working Paper Series in Economics No. 37, January 2007, www.unilueneburg.de/vwl/papers ISSN 1860 - 5508

Council on American-Islamic Relations (CAIR). 2002 to 2005 Annual Reports "The status of Muslim Civil Rights in the United States". Washington, DC. OH http://www.cair.com

Davila, Alberto and Mora, Marie T. 2005. Changes in the Earnings of Arab Men in the US Between 2000 and 2002. Journal of Population Economics (2005) 18: 587-601

Human Rights Watch. 2002. 'We are not the enemy': Hate crimes against Arabs, Muslims and those perceived to be Arab or Muslim after September 11. Human Rights Watch Report 14 , no. 6(G) (November).

Ibish, H., and A. Stewart. 2003. Report on hate crimes and discrimination against Arab Americans: The post-September 11 backlash. Washington, DC: American-Arab AntiDiscrimination Committee.

Kaestner, Robert, Kaushal Neeraj and Reimers Cordelia, 2007. Labor Market Effects of September $11^{\text {th }}$ on Arab and Muslim Residents of the United States. The Journal of Human Resources, Volume 42, Issue 2, Spring 2007.1Hnk464@columbia.edu 
Leonard, Karen I. 2003. Muslims in the United States, The State of Research.

Lindkvist, Heather. 2002, How to Restore Hope? Life After September 11 for the Somali Community in Maine. Paper presented to the Conference on Muslim Minorities in Western Europe and North America After September 11, Duke University, Durham, N.C. (March 23).

Moore, Kathleen M. 2002. American Attitudes Toward Immigration and Muslim Presence in the United States Since September 11. Paper presented to the Conference on Muslim Minorities in Western Europe and North America After September 11, Duke University, Durham, N.C. (March 23).

Orrenius, Pia M; Zavodny,Madeline. Did 9/11 worsen the job prospects of Hispanic immigrants? Federal Reserve Bank of Dallas, Working Paper number 05-08; http://dallasfed.org/research/papers/2005/wp0508.pdf

PEW Research Center; Muslim Americans, Middle Class and Mostly Mainstream; May 2007

Shryock, Andrew. 2002. New Images of Arab Detroit: Seeing Otherness and Identity Through the Lens of September 11. American Anthropologist 104(3): 917-22.

Suleiman, Michael W. 1999. Arabs in America, Building a New Future.

U.S. Bureau of the Census. 2003. The Arab population: 2000. Census 2000 Brief \#C2KBR-23, December.

U. S. Federal Bureau of Investigation. 2001. Hate Crime Report. http://www.fbi.gov/ucr/01hate.pdf 
Table 1: Non-regression Adjusted Difference in Difference Estimates for $1^{\text {st }}$ and $2^{\text {nd }}$ Generation Immigrant Men Age 16 to 25 Target Groups: Immigrants from Muslim-Majority Countries. Comparison Group 1: Other Immigrants

(Standard Errors in Parentheses)

\begin{tabular}{|c|c|c|c|}
\hline Variable & $\begin{array}{l}\text { Target Group A (Narrow Group) } \\
\text { (Mid Eastern, Iranians, Afghan) }\end{array}$ & $\begin{array}{l}\text { Target Group B (In-Between Group) } \\
\text { (Group A, Pakistanis, African Arabs) }\end{array}$ & $\begin{array}{c}\text { Target Group C (Broad Group) } \\
\text { (All Special Registration Countries) }\end{array}$ \\
\hline \multicolumn{4}{|l|}{ Employment } \\
\hline $\begin{array}{l}\text { Jan. } 99 \text { to Sept. } 01 \\
\text { Oct. } 01 \text { to Dec. } 02 \\
\text { Oct. } 01 \text { to Dec. } 04\end{array}$ & $\begin{array}{c}- \\
-.166+ \\
(0.089) \\
-.025 \\
(0.040)\end{array}$ & $\begin{array}{c}- \\
-0.119+ \\
(0.071) \\
0.022 \\
(0.050)\end{array}$ & $\begin{array}{c}- \\
-0.060 \\
(0.062) \\
0.010+ \\
(0.005)\end{array}$ \\
\hline \multicolumn{4}{|l|}{ Hours Worked } \\
\hline $\begin{array}{l}\text { Jan. } 99 \text { to Sept. } 01 \\
\text { Oct. } 01 \text { to Dec. } 02 \\
\text { Oct. } 01 \text { to Dec. } 04\end{array}$ & $\begin{array}{c}- \\
-7.73+ \\
(3.38) \\
-2.83 \\
(0.16)\end{array}$ & $\begin{array}{c}- \\
-5.93 \\
(3.9) \\
-3.63 \\
(2.3)\end{array}$ & $\begin{array}{c}- \\
-4.2 \\
(2.8) \\
-1.7 \\
(2.09)\end{array}$ \\
\hline \multicolumn{4}{|l|}{ Real Weekly Earnings } \\
\hline $\begin{array}{l}\text { Jan. } 99 \text { to Sept. } 01 \\
\text { Oct. } 01 \text { to Dec. } 02 \\
\text { Oct. } 01 \text { to Dec. } 04\end{array}$ & $\begin{array}{c}- \\
-27.13 \\
(40.11) \\
-7.53 \\
(27.5)\end{array}$ & $\begin{array}{c}- \\
-0.23 \\
(32.9) \\
6.57 \\
(23.0)\end{array}$ & $\begin{array}{c}- \\
-1.0 \\
(29.0) \\
34 \\
(20.9)\end{array}$ \\
\hline $\begin{array}{l}\text { Notes: Entries ar } \\
\text { Appendix I. A “* }\end{array}$ & ifference es & In Appen & $\begin{array}{l}\text { definitions are reported } \\
\text { ificance at the } 10 \% \text { leve }\end{array}$ \\
\hline
\end{tabular}


Table 2: Difference-in-differences Effects of 9/11 on Labor Market Outcomes of Immigrants form Muslim-Majority Countries Relative to Other Immigrants Living in the US

\begin{tabular}{|c|c|c|c|c|c|c|c|c|c|c|}
\hline & & \multicolumn{3}{|c|}{$\begin{array}{c}\text { Target A (Narrow) } \\
\text { (Mid Eastern, Iranians, Afghan) }\end{array}$} & \multicolumn{3}{|c|}{$\begin{array}{l}\text { Target B (In-Between Group) } \\
\text { (Group A, Pakistanis, African Arabs) }\end{array}$} & \multicolumn{3}{|c|}{$\begin{array}{l}\text { Target C, (Broad Group) } \\
\text { (All Special Registration countries) }\end{array}$} \\
\hline & & Age 16-25 & Age 16-29 & Age 16-64 & Age 16-25 & Age 16-29 & Age 16-64 & Age 16-25 & Age 16-29 & Age 16-64 \\
\hline \multirow{9}{*}{ 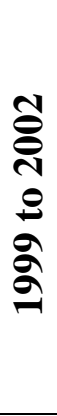 } & Employed=1 & -0.448 & -0.200 & -0.030 & $-0.379 *$ & -0.165 & -0.010 & $-0.292+$ & $-0.176+$ & -0.004 \\
\hline & & $(0.242)$ & $(0.153)$ & $(0.044)$ & $(0.163)$ & $(0.102)$ & $(0.038)$ & $(0.142)$ & $(0.091)$ & $(0.034)$ \\
\hline & Observations & 4142 & 7795 & 39374 & 4219 & 7907 & 40091 & 4321 & 8024 & 40535 \\
\hline & Weekly Hours & -17.032 & -7.912 & 0.097 & $-19.216+$ & -6.913 & -0.468 & $-10.778^{*}$ & -5.112 & -1.474 \\
\hline & & $(10.997)$ & (7.548) & $(2.051)$ & $(10.316)$ & $(7.639)$ & $(2.233)$ & $(4.949)$ & $(3.525)$ & $(1.648)$ \\
\hline & Observations & 4073 & 7575 & 38300 & 4152 & 7748 & 38990 & 4198 & 7850 & 39421 \\
\hline & Log weekly earnings & -0.176 & -0.104 & $-0.196 * *$ & 0.052 & 0.107 & $-0.142 *$ & 0.144 & $0.235+$ & $-0.096^{*}$ \\
\hline & & $(0.372)$ & $(0.245)$ & $(0.057)$ & $(0.243)$ & $(0.153)$ & $(0.067)$ & $(0.178)$ & $(0.131)$ & $(0.042)$ \\
\hline & Observations & 2997 & 5826 & 27468 & 3036 & 5933 & 27927 & 3064 & 6003 & 28250 \\
\hline \multirow{9}{*}{ 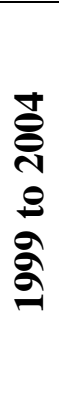 } & Employed = 1 & $-0.306+$ & 0.044 & -0.013 & -0.149 & 0.064 & -0.027 & -0.167 & -0.090 & -0.020 \\
\hline & & $(0.161)$ & $(0.087)$ & $(0.034)$ & $(0.112)$ & $(0.068)$ & $(0.028)$ & $(0.101)$ & $(0.060)$ & $(0.025)$ \\
\hline & Observations & 6136 & 11443 & 58250 & 6241 & 11592 & 59243 & 6314 & 11752 & 40709 \\
\hline & Weekly Hours & $-15.865^{* *}$ & -3.575 & -1.07 & $-16.383^{*}$ & -5.124 & $-1.783+$ & $-7.659^{*}$ & -2.537 & -1.315 \\
\hline & & $(5.699)$ & $(4.412)$ & $(1.085)$ & $(6.161)$ & $(5.082)$ & $(0.905)$ & $(2.874)$ & $(2.749)$ & $(0.947)$ \\
\hline & Observations & 6037 & 11128 & 56714 & 6148 & 11355 & 57672 & 6216 & 11501 & 58296 \\
\hline & Log weekly earnings & 0.024 & 0.069 & $-0.060+$ & 0.231 & 0.166 & $-0.090+$ & $0.257+$ & $0.214 * *$ & -0.022 \\
\hline & & $(0.122)$ & $(0.125)$ & $(0.034)$ & $(0.186)$ & $(0.111)$ & $(0.052)$ & $(0.142)$ & $(0.074)$ & $(0.024)$ \\
\hline & Observations & 4396 & 8468 & 40359 & 4457 & 8615 & 40996 & 4497 & 8713 & 41468 \\
\hline
\end{tabular}

Notes: For earnings and hours worked models, robust standard errors clustered by repeated observations are shown in parentheses.

Statistical Significance: + significant at 10\%; * significant at 5\%; ** significant at 1\%. For employment-population ratio, the effects are difference-in-differences of probabilities predicted by probit models. The difference-in-differences effects were predicted for each individual separately. Standard errors shown

in parentheses were calculated using the delta method. Explanatory variables were Muslim, 9-11 dummy variable, race and ethnicity, state, potential experience,

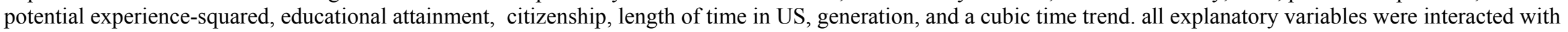
Muslim dummy (except race, citizenship, experience, cubic time trend and log of state per-capita income). 
Table-3: Difference-in-differences effects on the Weekly Earnings of Immigrants from all Special Registration Countries Compared to Other Immigrants (Target Group C)

Effects at shown at the $25^{\text {th }}, 50^{\text {th }}, 75^{\text {th }}$ and the $90^{\text {th }}$ Quantiles

\begin{tabular}{|c|c|c|c|c|c|c|c|c|}
\hline \multirow[b]{2}{*}{ Quantiles: } & \multicolumn{4}{|c|}{1999 to 2002} & \multicolumn{4}{|c|}{1999 to 2004} \\
\hline & 0.25 & 0.50 & 0.75 & 0.90 & 0.25 & 0.50 & 0.75 & 0.90 \\
\hline \multicolumn{9}{|l|}{ Age 16-25 } \\
\hline $\begin{array}{c}\text { Muslim*After 9-11 } \\
\text { Observations }\end{array}$ & $\begin{array}{c}-0.501+ \\
(0.261) \\
3521\end{array}$ & $\begin{array}{c}-0.003 \\
(0.173) \\
3521\end{array}$ & $\begin{array}{c}0.038 \\
(0.120) \\
3521\end{array}$ & $\begin{array}{c}0.218+ \\
(0.114) \\
3521\end{array}$ & $\begin{array}{c}-0.011 \\
(0.183) \\
5185\end{array}$ & $\begin{array}{c}-0.078 \\
(0.127) \\
5185\end{array}$ & $\begin{array}{c}0.071 \\
(0.088) \\
5185\end{array}$ & $\begin{array}{c}0.175+ \\
(0.094) \\
5185\end{array}$ \\
\hline \multicolumn{9}{|l|}{ Age 16-29 } \\
\hline Muslim*After 9-11 & $\begin{array}{l}-0.293 \\
(0.196)\end{array}$ & $\begin{array}{l}0.142+ \\
(0.079)\end{array}$ & $\begin{array}{c}0.349 * * \\
(0.111)\end{array}$ & $\begin{array}{c}0.034 \\
(0.136)\end{array}$ & $\begin{array}{l}-0.211 \\
(0.146)\end{array}$ & $\begin{array}{l}0.096+ \\
(0.055)\end{array}$ & $\begin{array}{c}0.316^{* *} \\
(0.078)\end{array}$ & $\begin{array}{c}0.147 \\
(0.101)\end{array}$ \\
\hline Observations & 6687 & 6687 & 6687 & 6687 & 9737 & 9737 & 9737 & 9737 \\
\hline Age 16-64 & & & & & & & & \\
\hline Muslim*After 9-11 & $\begin{array}{l}-0.107 \\
(0.073)\end{array}$ & $\begin{array}{l}-0.097 * \\
(0.048)\end{array}$ & $\begin{array}{l}-0.022 \\
(0.056)\end{array}$ & $\begin{array}{c}0.033 \\
(0.060)\end{array}$ & $\begin{array}{l}-0.054 \\
(0.061)\end{array}$ & $\begin{array}{l}-0.017 \\
(0.042)\end{array}$ & $\begin{array}{l}-0.015 \\
(0.042)\end{array}$ & $\begin{array}{c}0.013 \\
(0.048)\end{array}$ \\
\hline Observations & 30651 & 30651 & 30651 & 30651 & 45149 & 45149 & 45149 & 45149 \\
\hline
\end{tabular}

Notes: Standard errors are shown in parentheses. Statistical Significance: + means significant at 10\%; * means significant at 5\%; ** means significant at 1\%. For Unemployed and Out-of-Labor force individuals, log-earnings was assigned a value of zero. The effects of divisions, unemployment rates, state per-capita incomes, occupations and educational attainment were allowed to vary by the target group. Target Group $\mathrm{C}$ consists of 1 st and 2 nd generation immigrants from all but two Special Registration countries. Comparison Group 1 consists of 1st and 2nd generation immigrants excluding those from countries in Target Group C, Mexico, Central America, the Caribbean, Turkey, Malaysia, India, Ghana, Kenya, Nigeria and "Other-Africa. 
Table 4: Difference-in-Differences Estimates from Using the Months Between January-1998 and August 2001 with August 2000 as the Intervention Date Effects for Target Groups A, B and C compared to Other Immigrants

\begin{tabular}{|c|c|c|c|c|c|c|c|c|c|c|}
\hline & & \multicolumn{3}{|c|}{ Target Group A } & \multicolumn{3}{|c|}{ Target Group B } & \multicolumn{3}{|c|}{ Target Group C } \\
\hline & & $\begin{array}{c}\text { Age } \\
16-25 \\
\end{array}$ & $\begin{array}{c}\text { Age } \\
16-29 \\
\end{array}$ & $\begin{array}{c}\text { Age } \\
16-64 \\
\end{array}$ & $\begin{array}{c}\text { Age } \\
16-25 \\
\end{array}$ & $\begin{array}{c}\text { Age } \\
16-29 \\
\end{array}$ & $\begin{array}{c}\text { Age } \\
16-64 \\
\end{array}$ & $\begin{array}{c}\text { Age } \\
16-25 \\
\end{array}$ & $\begin{array}{c}\text { Age } \\
16-29 \\
\end{array}$ & $\begin{array}{c}\text { Age } \\
16-64\end{array}$ \\
\hline \multirow{7}{*}{ 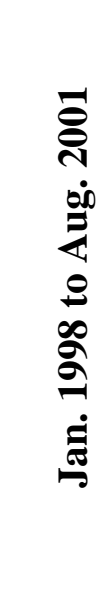 } & Employment & -0.074 & 0.01 & -0.024 & -0.051 & 0.042 & -0.011 & 0.046 & 0.064 & -0.014 \\
\hline & & $(0.081)$ & $(0.042)$ & $(0.025)$ & $(0.082)$ & $(0.033)$ & $(0.027)$ & $(0.094)$ & $(0.040)$ & $(0.027)$ \\
\hline & Observations & 3872 & 7279 & 36660 & 3836 & 7190 & 36282 & 3775 & 7056 & 35675 \\
\hline & $\begin{array}{l}\text { Log weekly } \\
\text { earnings }\end{array}$ & $\begin{array}{l}-0.097 \\
(0.080)\end{array}$ & $\begin{array}{l}-0.113 \\
(0.079)\end{array}$ & $\begin{array}{c}0.045 \\
(0.029)\end{array}$ & $\begin{array}{c}0.031 \\
(0.088)\end{array}$ & $\begin{array}{l}-0.049 \\
(0.055)\end{array}$ & $\begin{array}{c}0.037 \\
(0.030)\end{array}$ & $\begin{array}{l}-0.096 \\
(0.073)\end{array}$ & $\begin{array}{l}-0.115 \\
(0.093)\end{array}$ & $\begin{array}{c}0.052 \\
(0.038)\end{array}$ \\
\hline & Observations & 2783 & 2783 & 25639 & 2760 & 5419 & 25360 & 2729 & 5337 & 24963 \\
\hline & $\begin{array}{c}\text { Weekly Hours } \\
\text { Worked }\end{array}$ & $\begin{array}{l}-3.242 \\
(3.557)\end{array}$ & $\begin{array}{c}1.131 \\
(2.095)\end{array}$ & $\begin{array}{l}-1.102 \\
(1.498)\end{array}$ & $\begin{array}{l}-1.747 \\
(3.698)\end{array}$ & $\begin{array}{c}2.908 \\
(2.261)\end{array}$ & $\begin{array}{l}-1.053 \\
(1.658)\end{array}$ & $\begin{array}{c}0.329 \\
(4.081)\end{array}$ & $\begin{array}{c}1.492 \\
(2.598)\end{array}$ & $\begin{array}{l}-1.716 \\
(1.606)\end{array}$ \\
\hline & Observations & 3793 & 7104 & 35593 & 3757 & 7017 & 35226 & 3698 & 6889 & 34652 \\
\hline $\begin{array}{l}\text { Notes: } \\
\text { August } \\
\text { and C a } \\
* \text { signif } \\
\text { probit n }\end{array}$ & $\begin{array}{l}\text { bers show the dif } \\
\text { and used Septem } \\
\text { mparison group } \\
\text { at } 5 \% \text {; * signifi } \\
\text { s. None of the es }\end{array}$ & $\begin{array}{l}\text {-in-diffe } \\
99 \text { as the } \\
\text { ist Stand } \\
1 \% . \text { Eff } \\
\text { s are stat }\end{array}$ & $\begin{array}{l}\text { effects } \\
\text { after w } \\
\text { ors clust } \\
\text { Earning } \\
\text { y signifi }\end{array}$ & $\begin{array}{l}\text { e model } \\
\text { e"Post } \\
\text { y repeate } \\
\text { Hours w }\end{array}$ & $\begin{array}{l}\text { udo } 9-1 \\
\text { hy was a } \\
\text { ons are i } \\
\text { given by }\end{array}$ & $\begin{array}{l}\text { We tool } \\
\text { d a value } \\
\text { ntheses. } \\
\text { regressic }\end{array}$ & $\begin{array}{l}\text { lonthly d } \\
\text { e. Model } \\
\text { tical Sig } \\
\text { d effects }\end{array}$ & $\begin{array}{l}\text { nuary } 1 \\
\text { for targ } \\
\text { - Signif } \\
\text { ment w }\end{array}$ & $\begin{array}{l}\text { ough } \\
\text { o, B } \\
10 \% \\
\text { n }\end{array}$ & \\
\hline
\end{tabular}


Table 5: Relative Changes in the Labor Market Outcomes of Muslim Men Age 16 to 25 after Various Dates (Regression Adjusted Difference-in-differences effects and Standard Errors are shown)

\begin{tabular}{|c|c|c|c|c|c|c|c|c|c|}
\hline \multirow[b]{2}{*}{ Dates } & \multicolumn{3}{|c|}{ Mid-Eastern \& Afghan men (Group A) } & \multicolumn{3}{|c|}{ Mid-Eastern, Afghan \& African men (Group B) } & \multicolumn{3}{|c|}{ Men from All SR Countries (Group C) } \\
\hline & EPOP & Hours Worked & Log Earnings & EPOP & Hours Worked & Log Earnings & EPOP & Hours Worked & Log Earnings \\
\hline \multirow[t]{2}{*}{ Mar-01 } & 0.041 & 0.650 & -0.102 & 0.083 & 2.563 & -0.131 & 0.030 & 1.932 & -0.081 \\
\hline & $(0.101)$ & $(4.647)$ & $(0.176)$ & $(0.090)$ & $(3.935)$ & $(0.142)$ & $(0.080)$ & $(3.732)$ & $(0.157)$ \\
\hline \multirow[t]{2}{*}{ Jun-01 } & -0.130 & -8.242 & 0.117 & -0.048 & -5.113 & 0.008 & -0.109 & -5.368 & 0.094 \\
\hline & $(0.114)$ & $(5.367)$ & $(0.195)$ & $(0.090)$ & $(4.174)$ & $(0.160)$ & $(0.080)$ & (3.909) & $(0.174)$ \\
\hline \multirow[t]{2}{*}{ Sep-01 } & $-0.267 * *$ & $-15.744^{*}$ & 0.187 & -0.130 & $-7.362+$ & 0.257 & $-0.160+$ & $-8.051 * *$ & 0.257 \\
\hline & $(0.121)$ & $(5.639)$ & $(0.237)$ & $(0.100)$ & (4.449) & $(0.171)$ & $(0.090)$ & (4.059) & $(0.170)$ \\
\hline \multirow[t]{2}{*}{ Dec-01 } & $-0.263^{*}$ & $-10.401^{* *}$ & 0.328 & $-0.156+$ & $-6.724+$ & $0.285+$ & $-0.197 * *$ & $-8.815^{* *}$ & 0.211 \\
\hline & $(0.099)$ & $(4.730)$ & $(0.201)$ & $(0.080)$ & (3.829) & $(0.150)$ & $(0.080)$ & (3.604) & $(0.151)$ \\
\hline \multirow[t]{2}{*}{ Mar-02 } & -0.134 & $-8.629+$ & $0.351+$ & -0.050 & -3.720 & $0.334 * *$ & -0.104 & -5.364 & $0.292 * *$ \\
\hline & $(0.108)$ & $(4.931)$ & $(0.189)$ & $(0.080)$ & (3.648) & $(0.138)$ & $(0.070)$ & (3.404) & $(0.137)$ \\
\hline \multirow[t]{2}{*}{ Jun-02 } & -0.137 & -6.698 & $0.339+$ & -0.045 & -1.990 & $0.386^{*}$ & $-0.116+$ & $-5.097+$ & $0.290^{* *}$ \\
\hline & $(0.095)$ & $(4.185)$ & $(0.184)$ & $(0.070)$ & (3.069) & $(0.134)$ & $(0.060)$ & $(2.861)$ & $(0.129)$ \\
\hline \multirow[t]{2}{*}{ Sep-02 } & -0.122 & -5.922 & $0.377^{* *}$ & -0.021 & -0.983 & $0.401^{*}$ & -0.069 & -2.942 & $0.301^{* *}$ \\
\hline & $(0.090)$ & $(4.027)$ & $(0.171)$ & $(0.070)$ & (2.917) & $(0.128)$ & $(0.060)$ & $(2.763)$ & $(0.124)$ \\
\hline \multirow[t]{2}{*}{ Dec-02 } & 0.000 & -1.725 & $0.497 *$ & 0.052 & 1.517 & $0.359^{*}$ & -0.001 & -0.802 & $0.274 * *$ \\
\hline & $(0.088)$ & (3.881) & $(0.158)$ & $(0.070)$ & $(2.861)$ & $(0.124)$ & $(0.060)$ & (2.683) & $(0.119)$ \\
\hline \multirow[t]{2}{*}{ Mar-03 } & -0.037 & -3.430 & $0.368^{* *}$ & 0.034 & 0.683 & $0.277^{* *}$ & 0.001 & -0.965 & $0.222 * *$ \\
\hline & $(0.085)$ & (3.747) & $(0.147)$ & $(0.070)$ & $(2.813)$ & $(0.108)$ & $(0.060)$ & $(2.657)$ & $(0.104)$ \\
\hline
\end{tabular}

Notes: Each regression uses 6,149 observations. Robust standard errors clustered by repeated observations are shown in parentheses. A “+” denotes significance at $10 \%$. A “*”
denotes significance at $5 \%$, and “**” denotes significance at $1 \%$. Explanatory variables are potential experience, experience-squared, state-unemployment rates, cubic-time trend, denotes significance at $5 \%$, and “**” denotes significance at $1 \%$. Explanatory variables are potential experience, experience-squared, state-unemployment rates, cubic-time trend,
state-level ratio of Muslim to non-Muslim populations and dummies for Muslim, After-9/11, races, states, education, citizenship status, length of stay and generation in the US. Explanatory variables were interacted with the Muslim dummy variable. Special Registration countries include Afghanistan, Bangladesh, Egypt, Indonesia,

Middle Eastern Arab countries, Iran, Libya, Morocco, North Africa and Pakistan. Comparison Group consists of $1^{\text {st }}$ and $2^{\text {nd }}$ generation immigrants excluding those from the Special Registration countries, Mexico Central America, the Caribbean, Turkey, Malaysia, India, Ghana, Kenya, Nigeria, and "Other-Africa". 



\section{Appendix I: Target and Comparison Group Definitions}

Muslims: Immigrants from Muslim-majority countries.

\section{TARGET GROUPS:}

Target Group C (the Broad Group): $1^{\text {st }}$ and $2^{\text {nd }}$ generation immigrants from most Countries under Special Registration Program. (Afghanistan, Bangladesh, Egypt, Indonesia, Middle Eastern Arab countries Iran, Libya, Morocco, North Africa and Pakistan.).

Target Group B (the In-between Group): $1^{\text {st }}$ and $2^{\text {nd }}$ generation immigrants from Afghanistan, Middle Eastern Arab countries, Iran, Pakistan, Egypt and Morocco

Target Group A (the Narrow Group): $1^{\text {st }}$ and $2^{\text {nd }}$ generation immigrants from Middle Eastern Arab countries, Iran and Afghanistan

\section{COMPARISON GROUPS:}

Comparison Group 1: $1^{\text {st }}$ and $2^{\text {nd }}$ generation immigrants excluding Target group C, Mexico, Central America, the Caribbean, Turkey, Malaysia, India, Ghana, Kenya, Nigeria and "OtherAfrica".

Comparison Group 2: All US-born men excluding Target group C.

Comparison Group 3: All US-born non-Hispanic Whites excluding target group C. 
Appendix II: Descriptive Statistics for $1^{\text {st }}$ and $2^{\text {nd }}$ Generation Immigrant Men Age 16 to 25 living in the US

Target Groups: Immigrants from Muslim-Majority Countries. Comparison Group 1: Other Immigrants

\begin{tabular}{|c|c|c|c|c|}
\hline Variable & $\begin{array}{c}\text { Target Group A } \\
\text { (Mid Eastern Arabs, } \\
\text { Iranians, Afghan) } \\
\end{array}$ & $\begin{array}{c}\text { Target Group. B } \\
\text { (All Arabs, Iranians, } \\
\text { Afghan, South Asians) } \\
\end{array}$ & $\begin{array}{c}\text { Target Group. A } \\
\text { (Men from } \\
\text { all Special Registration Countries) } \\
\end{array}$ & $\begin{array}{c}\begin{array}{c}\text { Comparison Group 1 } \\
\text { (Immigrants from }\end{array} \\
\text { Non-Muslim-majority Countries) } \\
\end{array}$ \\
\hline \multicolumn{5}{|l|}{ Employment } \\
\hline Jan. 99 to Sept. 01 & 69.1 & $62.2 * *$ & $63.2 * *$ & 75.86 \\
\hline Observations & 68 & 127 & 163 & 2,784 \\
\hline Oct. 01 to Dec. 02 & $51.3 * *$ & $49.1 * *$ & $56.0^{* *}$ & 74.7 \\
\hline Observations & 37 & 55 & 75 & 1,253 \\
\hline Oct. 01 to Dec. 04 & $64.6^{* *}$ & $62.5 * *$ & $62.4 * *$ & 74.02 \\
\hline Observations & 113 & 160 & 197 & 3,168 \\
\hline \multicolumn{5}{|l|}{ Hours Worked per Week } \\
\hline Jan. 99 to Sept. 01 & 28.8 & $25.6^{*}$ & $26.3+$ & 29.36647 \\
\hline Observations & 67 & 124 & 160 & 2726 \\
\hline Oct. 01 to Dec. 02 & $20.4^{*}$ & $19.0^{* *}$ & $21.5^{* *}$ & 28.72358 \\
\hline Observations & 36 & 54 & 73 & 1230 \\
\hline Oct. 01 to Dec. 04 & $24.9 *$ & $20.9 * *$ & $23.6^{* *}$ & 28.30831 \\
\hline Observations & 111 & 157 & 194 & 3117 \\
\hline \multicolumn{5}{|l|}{ Real Weekly Earnings } \\
\hline Jan. 99 to Sept. 01 & 244.8 & $246.9^{*}$ & 241.0 & 247.3703 \\
\hline Observations & 52 & 81 & 100 & 2029 \\
\hline Oct. 01 to Dec. 02 & 222.1 & $251.1^{* *}$ & 245.2503 & 251.6574 \\
\hline Observations & 21 & 31 & 40 & 895 \\
\hline Oct. 01 to Dec. 04 & 214.6 & $230.8^{* *}$ & $268.7 * *$ & 240.6799 \\
\hline Observations & 71 & 103 & 124 & 2244 \\
\hline Age & 21.941 & 21.943 & 22.088 & 21.879 \\
\hline Spouse Present $=1$ & $8.333 * *$ & $8.755^{*}$ & $8.413^{*}$ & 13.364 \\
\hline Citizen $=1$ & $64.583 * *$ & 59.677 & 55.449 & 58.294 \\
\hline \multicolumn{5}{|l|}{ Education Categories } \\
\hline Below High school = 1 & $17.361^{*}$ & $17.05^{*}$ & $15.87^{*}$ & 27.915 \\
\hline High school Diploma $=1$ & 38.194 & 36.405 & 36.137 & 39.586 \\
\hline Some College $=1$ & 20.834 & $22.12+$ & $22.563^{*}$ & 18.516 \\
\hline Bachelors' Degree $=1$ & 12.847 & $15.207^{*}$ & $16.252 *$ & 10.657 \\
\hline Masters' or Above $=1$ & $10.764 *$ & $9.217^{*}$ & $9.178 *$ & 3.326 \\
\hline
\end{tabular}

Generation in USA 
1st Generation $=1$

3rd Generation $=1$

Length of Stay in USA

0 to 5 years $=1$

5 to 10 years $=1$

$10+$ years $=1$

\section{Major Occupation Groups}

Managers and Administrators

\section{Professional}

Associate Prof. \& technical

Clerical and Secretarial

Craft and related

Personal and Protective

Sales

Plant and Machine operatives

Other

\section{Major Industry Groups}

Agriculture \& Fishing

Energy \& Water

Manufacturing

Construction

Distribution, Hotels \& Restaurants

Transport \& Communication

Banking, Finance \& Insurance

Public admin, Education \& Health

\section{Other Services}

Total Observations
52.778

47.222

57.834

42.166

21.199

17.973

60.83

15.625
66.667

4.928

4.238

10.169

3.39

12.288

17.373

4.661

$25^{*}$

$20.3 *$

$2.5 *$

0.847

0

$8.1+$

$5.1 *$

$46.6^{*}$

5.509

13.56

8.475

11.864
$61.951+$

38.049+

23.71+

21.224

$55.067 * *$

6.265

12.048

3.132

11.807

17.109

$4.578+$

$21.205+$

$21.2 * *$

2.651

0.723

0.241

$7.711^{* *}$

4.819*

43.855*

7.711

16.627

7.229

11.084
$53.093 *$

46.907*

$17.573^{*}$

$16.64 *$

$65.788^{*}$

3.985

9.556

2.04

$9.771 * *$

$21.272+$

4.414

10.94

$30.434 * *$

7.588

1.718

0.453

$12.276^{*}$

$12.419 *$

32.844*

$5.345 * *$

15.45

8.053

11.441

9527

Notes: All variables except real weekly earning, hours worked per week and age are categorical. Means are shown for variables for each target and comparison group. Whenever

difference between a target group's outcome is statistical significant, the target group's outcome is marked with asterisk(s): ** means significant at $1 \%$ level, * means significant at $5 \%$ level, + means significant at $10 \%$ level. 
Appendix III: Relative Changes in the Labor Market Outcomes of Muslim Men Age 16 to 29 after Various Dates (Regression Adjusted Difference-in-differences effects and Standard Errors are shown)

\begin{tabular}{|c|c|c|c|c|c|c|c|c|c|}
\hline \multirow[b]{2}{*}{$\underline{\text { Dates }}$} & \multicolumn{3}{|c|}{ Mid-Eastern \& Afghan Men (Group A) } & \multicolumn{3}{|c|}{ Mid-Eastern, Afghan \& African Men (Group B) } & \multicolumn{3}{|c|}{ Men from All SR Countries (Group C) } \\
\hline & EPOP & Hours Worked & Log Earnings & EPOP & Hours Worked & Log Earnings & EPOP & Hours Worked & Log Earnings \\
\hline \multirow[t]{2}{*}{ Mar-01 } & 0.069 & 3.802 & 0.046 & 0.024 & 2.876 & -0.009 & -0.044 & 0.489 & 0.070 \\
\hline & $(0.081)$ & $(4.027)$ & $(0.154)$ & $(0.060)$ & $(2.921)$ & $(0.117)$ & $(0.054)$ & $(2.702)$ & $(0.117)$ \\
\hline \multirow[t]{2}{*}{ Jun-01 } & 0.006 & -0.004 & 0.121 & -0.038 & -0.384 & 0.072 & $-0.106+$ & -2.722 & 0.157 \\
\hline & $(0.088)$ & $(4.446)$ & $(0.176)$ & $(0.061)$ & $(3.028)$ & $(0.123)$ & $(0.056)$ & $(2.784)$ & $(0.122)$ \\
\hline \multirow[t]{2}{*}{ Sep-01 } & -0.046 & -4.064 & -0.053 & -0.062 & -2.719 & 0.081 & -0.096 & -3.741 & 0.194 \\
\hline & $(0.099)$ & (4.796) & $(0.172)$ & $(0.070)$ & $(3.277)$ & $(0.128)$ & $(0.063)$ & $(2.967)$ & $(0.122)$ \\
\hline \multirow[t]{2}{*}{ Dec-01 } & -0.052 & -1.947 & -0.034 & -0.084 & -3.677 & 0.094 & -0.081 & -3.563 & 0.116 \\
\hline & $(0.087)$ & $(4.066)$ & $(0.164)$ & $(0.062)$ & (3.017) & $(0.113)$ & $(0.057)$ & $(2.714)$ & $(0.105)$ \\
\hline \multirow[t]{2}{*}{ Mar-02 } & -0.046 & -2.868 & 0.015 & -0.059 & -3.195 & 0.136 & -0.060 & -3.016 & $0.164+$ \\
\hline & $(0.080)$ & $(3.658)$ & $(0.147)$ & $(0.056)$ & $(2.648)$ & (0.099) & $(0.051)$ & $(2.391)$ & $(0.092)$ \\
\hline \multirow[t]{2}{*}{ Jun-02 } & -0.016 & -0.511 & 0.016 & -0.027 & -0.657 & 0.140 & -0.043 & -1.658 & 0.117 \\
\hline & $(0.074)$ & $(3.300)$ & $(0.132)$ & $(0.053)$ & $(2.398)$ & $(0.094)$ & $(0.047)$ & $(2.138)$ & $(0.084)$ \\
\hline \multirow[t]{2}{*}{ Sep-02 } & -0.027 & -0.874 & 0.072 & -0.016 & 0.106 & $0.162+$ & -0.018 & -0.225 & 0.123 \\
\hline & $(0.068)$ & (3.109) & $(0.124)$ & $(0.049)$ & $(2.238)$ & $(0.092)$ & $(0.044)$ & $(2.001)$ & $(0.082)$ \\
\hline \multirow[t]{2}{*}{ Dec-02 } & 0.039 & 0.641 & 0.134 & 0.017 & 0.537 & 0.148 & 0.003 & -0.363 & 0.089 \\
\hline & $(0.066)$ & $(3.046)$ & $(0.123)$ & $(0.049)$ & $(2.257)$ & $(0.095)$ & $(0.043)$ & (1.987) & $(0.086)$ \\
\hline \multirow[t]{2}{*}{ Mar-03 } & 0.036 & 1.016 & 0.056 & 0.022 & 0.631 & 0.080 & 0.005 & -0.364 & 0.053 \\
\hline & $(0.063)$ & $(2.945)$ & $(0.125)$ & $(0.048)$ & $(2.297)$ & $(0.096)$ & $(0.043)$ & $(2.018)$ & $(0.088)$ \\
\hline \multicolumn{10}{|c|}{ 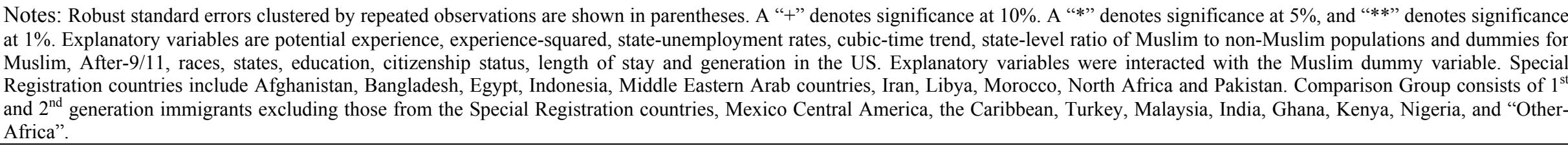 } \\
\hline
\end{tabular}


Appendix IV: Relative Changes in the Labor Market Outcomes of Muslim Men Age 16 to 64 after Various Dates

(Regression Adjusted Difference-in-differences effects and Standard Errors are shown)

\begin{tabular}{|c|c|c|c|c|c|c|c|c|c|}
\hline \multirow[b]{2}{*}{ Dates } & \multicolumn{3}{|c|}{ Mid-Eastern \& Afghan Men (Group A) } & \multicolumn{3}{|c|}{ Mid-Eastern, Afghan \& African men (Group B) } & \multicolumn{3}{|c|}{ Men from All SR Countries (Group C) } \\
\hline & EPOP & Hours Worked & Log Earnings & EPOP & Hours Worked & Log Earnings & EPOP & Hours Worked & Log Earnings \\
\hline \multirow[t]{2}{*}{ Mar-01 } & -0.004 & 0.242 & 0.011 & -0.01 & -0.114 & -0.005 & -0.027 & -0.929 & 0.014 \\
\hline & $(0.029)$ & $(1.615)$ & $(0.064)$ & $(0.023)$ & $(1.278)$ & $(0.053)$ & $(0.021)$ & $(1.168)$ & $(0.049)$ \\
\hline \multirow[t]{2}{*}{ Jun-01 } & -0.026 & -0.226 & 0.026 & -0.034 & -0.665 & 0.012 & $-0.041+$ & -1.253 & 0.021 \\
\hline & $(0.033)$ & (1.814) & $(0.070)$ & $(0.027)$ & $(1.458)$ & $(0.058)$ & $(0.024)$ & (1.302) & $(0.053)$ \\
\hline \multirow[t]{2}{*}{ Sep-01 } & -0.004 & -1.057 & -0.113 & -0.02 & -1.375 & -0.07 & -0.016 & -1.284 & -0.047 \\
\hline & $(0.035)$ & (1.867) & $(0.073)$ & $(0.028)$ & (1.503) & $(0.060)$ & $(0.025)$ & (1.344) & $(0.056)$ \\
\hline \multirow[t]{2}{*}{ Dec-01 } & -0.032 & -1.376 & -0.089 & $-0.050 * *$ & $-2.718^{* *}$ & -0.07 & $-0.036+$ & $-2.233+$ & $-0.082+$ \\
\hline & $(0.029)$ & $(1.575)$ & $(0.066)$ & $(0.024)$ & $(1.316)$ & $(0.052)$ & $(0.021)$ & $(1.172)$ & $(0.048)$ \\
\hline \multirow[t]{2}{*}{ Mar-02 } & 0.007 & 0.403 & -0.045 & -0.009 & -0.584 & -0.031 & -0.007 & -0.654 & -0.031 \\
\hline & $(0.026)$ & (1.398) & $(0.062)$ & $(0.021)$ & $(1.160)$ & $(0.048)$ & $(0.019)$ & $(1.032)$ & $(0.043)$ \\
\hline \multirow[t]{2}{*}{ Jun-02 } & 0.008 & 0.313 & -0.052 & -0.005 & -0.165 & -0.045 & -0.009 & -0.503 & -0.054 \\
\hline & $(0.024)$ & $(1.295)$ & $(0.054)$ & $(0.020)$ & (1.064) & $(0.044)$ & $(0.018)$ & $(0.942)$ & $(0.039)$ \\
\hline \multirow[t]{2}{*}{ Sep- 02} & 0.014 & 0.397 & -0.043 & -0.002 & -0.132 & -0.015 & -0.001 & -0.26 & -0.039 \\
\hline & $(0.023)$ & $(1.260)$ & $(0.052)$ & $(0.019)$ & (1.031) & $(0.041)$ & $(0.017)$ & $(0.919)$ & $(0.037)$ \\
\hline \multirow[t]{2}{*}{ Dec-02 } & 0.02 & 0.597 & -0.019 & 0.007 & 0.146 & -0.001 & 0.004 & -0.052 & -0.024 \\
\hline & $(0.022)$ & (1.196) & $(0.050)$ & $(0.018)$ & $(1.000)$ & $(0.041)$ & $(0.016)$ & $(0.893)$ & $(0.037)$ \\
\hline \multirow[t]{2}{*}{ Mar-03 } & 0.034 & 1.389 & -0.007 & 0.014 & 0.533 & 0.003 & 0.014 & 0.535 & -0.015 \\
\hline & $(0.021)$ & $(1.123)$ & $(0.057)$ & $(0.017)$ & $(0.952)$ & $(0.045)$ & $(0.016)$ & $(0.862)$ & $(0.039)$ \\
\hline
\end{tabular}

Notes: Robust standard errors clustered by repeated observations are shown in parentheses. A "+" denotes significance at $10 \%$. A “*” denotes significance at $5 \%$, and “**” denotes significance at $1 \%$. Explanatory variables are potential experience, experience-squared, state-unemployment rates, cubic-time trend, state-level ratio of Muslim to non-Muslim populations and dummies for Muslim, After-9/11, races, states, education, citizenship status, length of stay and generation in the US. Explanatory variables were interacted with the Muslim dummy variable. Special Registration countries include Afghanistan, Bangladesh, Egypt, Indonesia, Middle Eastern Arab countries, Iran, Libya, Morocco, North Africa and Pakistan. Comparison Group consists of $1^{\text {st }}$ and $2^{\text {nd }}$ generation immigrants excluding those from the Special Registration countries, Mexico Central America, the Caribbean, Turkey, Malaysia, India, Ghana, Kenya, Nigeria, and "Other-Africa". 
ENDNOTES

${ }^{1}$ The increase in reported incidences may exaggerate the increase in actual incidents for two reasons. First, reporting might have increased because CAIR's online reporting system became more familiar to Muslims after 9/11. Second, CAIR counts all hate-crime and discrimination reports, verified and not verified.

${ }^{2}$ According to US Equal Opportunity Commission (Washington, DC 20507) between 9/11/2001 and 12/11/2002, 705 charges were filed under Title VII with Process Type Z. - CAIR Annual Report 2002. For additional background, see for example, Baker et. Al (2003), Braakman (2007a, 2007b) Human Rights Watch (2002), Leonard (2003), Lindkvist (2002), Moore (2002), Shryock (2002) Suleiman (1999) and U.S. Census Bureau (2003).

${ }^{3}$ Lawyers Committee for Human Rights (www.lchr.org); September 2003 Report. “Assessing the New Normal: Liberty and Security of the Post-September 11 United States". Also see, Hate Crime Report (2001).

${ }^{4}$ On November 6, 2002, a Federal Register Notice was issued. "Call-In" Requirements for Special Registration for Males form specific countries. It was a system that would let the US government keep track of non-immigrants that come to the U.S. Any affected individual failing to follow these requirements was subject to lose his immigration status. Approximately 35 million non-immigrants were required to register with immigration authorities either at a port of entry or a designated immigration office in accordance with the special registration procedures. These special procedures also require additional in-person interviews at an immigration office and notifications to immigration authorities of changes of address, employment, or school. Non-immigrants who were to follow these special procedures would also have to use specially designated ports when they left USA and report in person to an immigration officer at the port on their departure date. Non-immigrant adult males from the following countries were called in for the program: Iran, Iraq, Libya, Sudan and Syria, Afghanistan, Algeria, Bahrain, Eritrea, Lebanon, Morocco, North Korea, Oman, Qatar, Somalia, Tunisia, United Arab Emirates, and Yemen, Pakistan, Saudi Arabia, Bangladesh, Egypt, Indonesia, Jordan and Kuwait.

${ }^{5}$ Using quantile earnings regressions Dávila and Mora show that the difference in earnings between Muslims and non-Muslims widened at all earnings deciles during 2002 relative to deciles in 2000. Their results from a Juhn, Murphy and Pierce decomposition reveal that the unexplained earning gaps increased in 2002 for Middle Eastern men. Unexpectedly, they find that earnings improved for African Arab men compared to non-Hispanic Whites. Their study also indicates that the decrease in earnings for Muslims was bigger in states with larger Muslim populations (i.e. in states where Muslims are more noticeable). They find that the earnings gap between Middle Eastern Arab men and non-Hispanic White men widened by about 35 percentage points and for men from Afghanistan, Iran and Pakistan the gap increased by about 29 percentage points in 2002.

${ }^{6}$ Kaestner et al. (2007) regress "earnings" for employed individuals. For their "hours-worked" regressions, they include all individuals setting hours equal to zero for men who were not employed. We do the same in the OLS regressions but for the quantile earning regressions, we include all men assigning log of earnings equal to zero if not employed. This is done to avoid the sample selection bias occurring in the mean regression.

7 The recession that began in March 2001 is potentially one such confounding factor. Estimation of the pre- and post-9/11 changes in outcome using only the target-group (i.e. Muslims) sample may generate a negative coefficient simply because of the business-cycle downturn.

${ }^{8}$ To control for industry of work, 9 major industry dummy variables were used. To control for occupations we constructed ten major occupation groups. However, we use "percentage of group members working in the respective occupation" to control for occupational variations instead of using occupation dummies. Exclusion of this variable does not significantly affect the difference in differences effect.

${ }^{9}$ We follow the specifications of Kaestner et al. (2004) here. We find coefficients of the time-trend variables always negligible and statistically insignificant. Models with month dummy variables yielded similar results.

${ }^{10}$ In the case of probit, the interaction effect is estimated by taking the average of difference-in-differences of the predicted probabilities.

${ }^{11}$ Kaestner et al. allowed the effect of September $11^{\text {th }}$ to differ according to an index of hate crime/discrimination against Arabs and Muslims. They used three measures of September 11th related hate crime or discrimination: 
number of hate crime/discrimination incidents reported in a state; number of hate crime/discrimination incidents per Arab population in a state; and number of hate crime/discrimination incidents per state population. While the first two capture the risk of discrimination Arabs and Muslims face in a state, the third is an indicator of the prevalence of prejudice among the non-Arab population. Prior to October 2001, value of hate-crime index was assumed to be zero in all states. They estimated the results using all three indices and found the effects of all of them to be statistically insignificant. Due to the insignificant effects and the limited nature of the data, we do not include the indices in the analyses.

${ }^{12}$ There has been no study on whether the $1^{\text {st }}$ generation immigrants were affected more than the $2^{\text {nd }}$-generation immigrants. Anti-terrorism laws and programs targeted primarily those $1^{\text {st }}$ generation immigrants who are not US citizens, especially those who are not residing or working legally in the US. A fraction of the $1^{\text {st }}$ generation immigrants in the CPS datasets should be illegal immigrants. Demographic research suggests that at least a fraction of the illegal immigrants are in the CPS since the number of immigrants enumerated by the survey (and by the decennial Census, upon which the CPS weights are based) exceeds estimates of the number of the foreign-born legally present in the U.S.

${ }^{13}$ Allen and Nielsen (2002) find that after 9/11, the single most predominant factor in determining who was to be a victim of an attack or infringement was their visual identity as a Muslim. This was found to be the case across reports from all $15 \mathrm{EU}$ member states. Also, there were seven reported cases of murders of Sikh men between September 2001 and February 2005. Sikhism is a religion, which in no way is affiliated to Islam. All of the cases appear to be hate-crimes. Details can be found here:

http://www.sikhcoalition.org/ListReports.asp

${ }^{14}$ Detroit Arab American Study-2003, University of Michigan; ICPSR Study No.: 4413; CAIR Annual Reports on Civil Rights Violations.

${ }^{15}$ Non-immigrant adult males from the following countries were called in for the special registration program: Iran, Iraq, Libya, Sudan, Syria, Afghanistan, Algeria, Bahrain, Eritrea, Lebanon, Morocco, North Korea, Oman, Qatar, Somalia, Tunisia, United Arab Emirates, Yemen, Pakistan, Saudi Arabia, Bangladesh, Egypt, Indonesia, Jordan and Kuwait. The CPS-MORG files do not separately identify Algeria, Libya, Somalia, Sudan, Tunisia and Eritrea. But they identify immigrants from North Africa, which consists of Algeria, Egypt, Libya, Morocco, Sudan, Tunisia and Western Sahara.

${ }^{16}$ The "Rest of Africa" which includes Somalia and Eritrea is dropped from the data. This is done to make sure that none of the comparison groups contains immigrants from the special registration program.

${ }^{17}$ Algeria, Libya and Tunisia cannot be identified separately but they are geographically included in North Africa. Most North African countries excluding Sudan were under the special registration list. Inclusion of North Africa might have created some contamination in Target group C. For Target group B, we dropped North Africa.

${ }^{18}$ The 2005 CAIR report shows that there were over 1500 alleged incidents of civil-rights violations against Muslims. 198 of them were reported as employment discrimination. Most of the victims in CAIR (2002 and 2005) and ADC (2003) reports had Arab, Afghanistan or Pakistani nativity. In its 2003 report, ADC (American-Arab Antidiscrimination Committee) mentions 800 cases and summarizes 101 cases of employment discrimination. None of the summary cases of employment discrimination were about Indian natives.

${ }^{19}$ Kaestner et al. included 20 states in their study. We excluded two of those states to keep number of younger Muslims reasonably large in each state.

${ }^{20}$ Immigrants from Mexico, Central America and the Caribbean are excluded because their educational achievement and language proficiency is not similar to other immigrants. Besides, a recent study (Orrenius and Zavodni, 2005) found that the relatively new immigrants from Mexico experienced a small drop in earnings after 911.

${ }^{21}$ Turkey and Malaysia were not listed under the special registration program but are Muslim-Majority country. None of the excluded African countries were enlisted for special registration but they have significant Muslim population and they are close to immigrants from Egypt and Morocco in terms of nativity and ethnicity. 
${ }^{22}$ Descriptive statistics for men age 16 to 64 are available upon request for all ages, around $85 \%$ of the observations in the target groups are $1^{\text {st }}$ generation immigrants whereas only $64 \%$ of the members of comparison group 1 are $1^{\text {st }}$ generation immigrants. On the other hand, in the youngest age group (ages 16 to 25 ) the distributions of $1^{\text {st }}$ and $2^{\text {nd }}$ generation are similar between target groups and comparison group 1 (around $60 \%$ are $1^{\text {st }}$ generation immigrants). Special registration and other similar legal requirements ensuing from 9/11 were targeted towards the first generation immigrants. If legal rigidities have had negative impacts on some group of workers (conditioning for other factors), one should find negative outcomes for the older Muslims (age 26 and up), as most of them are $1^{\text {st }}$ generation immigrants.

${ }^{23}$ They are available upon request.

${ }^{24}$ For the employment regressions, the difference-in-differences of employment-ratio was predicted for each observation separately and the mean of all the difference-in-differences is reported for each age-range under each target group in table 3. Standard errors were estimated for each prediction and the mean of those standard errors is shown in parentheses.

${ }^{25}$ The quantile regression results for the in-between group and the narrow group are available from the authors on request.

${ }^{26}$ Notice that the second set of months should start sufficiently long after 9-11, i.e. after the effect of the event dissipates.

${ }^{27}$ The results for the post-9/11 time window, i.e. the second set of months are available from the authors on request.

${ }^{28}$ We used nine intervention dates for the 1999-2002 time window. September 2001 and January 2002 interventions yield the largest relative drops in the employment of the youngest members of the target groups. The drops are around 30 to 35 percentage points and are statistically significant. If is worth mentioning here that for the narrow target group, the unadjusted regressions show nearly 14 to 18 percentage-point relative drops in employment after 911 for this shorter time-window. We used a shorter time-window, 1999 through 2002. Intervention dates close to 911 yield bigger employment effects for 16 to 25 year old Muslims

${ }^{29}$ Results available from authors on request.

${ }^{30}$ Regression estimates from using US-born men as comparison groups are available from the author on request. In regressions that included comparison groups 2 and 3, we drop citizenship status and length of stay variables to avoid multicollinearity problem. 